\title{
Insulin-like growth factor-I protects myoblasts from apoptosis but requires other factors to stimulate proliferation
}

\author{
J R Napier, M F Thomas, M Sharma, S C Hodgkinson and \\ J J Bass
}

AgResearch Ltd, Private Bag 3123, Hamilton, New Zealand

(Requests for offprints should be addressed to J R Napier)

\begin{abstract}
Insulin-like growth factor-I (IGF-I) has been shown to stimulate myoblast proliferation for a limited time after which serum is required to reactivate IGF-I-stimulated myoblast proliferation. The aim of these studies was to determine whether IGF-I can stimulate myoblast proliferation and/or inhibit apoptosis alone or whether co-factors are necessary. This was achieved by investigating the proliferative response of L6 myoblasts to IGF-I and horse serum (HS) and by examining the status of cells in terms of cell number, substrate adherence, cell viability and DNA laddering following incubation with IGF-I and HS.

L6 myoblasts proliferate in response to IGF-I for $36 \mathrm{~h}$; failure to respond to IGF-I after $36 \mathrm{~h}$ is not due to accumulation of waste products or lack of IGF-I. The addition of a low level $(1 \% \mathrm{v} / \mathrm{v})$ of HS restores the ability of myoblasts to proliferate in response to IGF-I and this supports the existence of a mitogenic competence factor. Furthermore, myoblasts failing to proliferate in response to
\end{abstract}

IGF-I after $36 \mathrm{~h}$ regain the capacity to respond to IGF-I for a further period of $36 \mathrm{~h}$ when exposed to fetal bovine serum.

Following the initial $(36 \mathrm{~h})$ phase of IGF-I-stimulated proliferation, removal of both IGF-I and HS led to a dramatic $(60 \%)$ reduction in the number of cells fully attached to the culture vessel, with $60 \%$ of the completely detached cells dead. Agarose gel electrophoresis of extracts from these detached cells revealed higher levels of DNA laddering than extracts prepared from attached cells with IGF-I present. This suggests that IGF-I acts as a survival factor by protecting cells from apoptosis. In conclusion these experiments support the presence of a mitogenic competence factor in horse serum, which restores the ability of cells to proliferate in response to IGF-I. Unlike proliferation, protection against apoptosis is achieved by IGF-I or HS independently of each other.

Journal of Endocrinology (1999) 163, 63-68

\section{Introduction}

Growth and development of muscle requires the proliferation, differentiation and fusion of myoblasts. Insulin-like growth factors (IGFs) are unique amongst growth factors in that they stimulate both proliferation and differentiation (Ewton \& Florini 1981, Ballard et al. 1986) suggesting that other factors may determine the response of myoblasts to IGF.

McWade et al. (1995) reported in an abstract that L6A1 myoblasts proliferate in response to IGF-I but only for $36 \mathrm{~h}$. They showed that cessation of proliferation was neither due to depletion of IGF-I nor to accumulation of waste products of cell metabolism secreted into the media. IGF-I-stimulated proliferation was restored by incubating cells with horse serum (HS) for $12 \mathrm{~h}$. This activity, which they named mitogenic competence factor (MCF), also inhibited IGF-I-stimulated differentiation.

The IGFs are also known to function as survival factors in several cell types. D'Mello et al. (1993) have shown that IGF-I will protect cultured rat cerebella granule neurons from low potassium-induced apoptosis. Stewart and Rotwein (1996) were able to block cell death in IGF-II antisense clones of the $\mathrm{C} 2$ muscle cell line using des[13]IGF-I, IGF-I, IGF-II or insulin with a dose potency appropriate for activation of the IGF-I receptor. These latter workers were also able to demonstrate that IGF-I added to low-serum differentiation media led to a $25-50 \%$ increase in the number of adherent myoblasts.

The aim of these studies was to determine whether IGF-I can stimulate myoblast proliferation and/or inhibit apoptosis alone or whether co-factors are necessary. This was studied by investigating the proliferative response of L6 myoblasts to IGF-I and HS and by examining the status of cells in terms of cell number, substrate adherence and viability following incubation with IGF-I and HS in order 
to determine the effect of IGF-I on proliferation and cell death of myoblasts.

\section{Materials and Methods}

\section{Cell culture}

L6 myoblast cultures (Yaffe 1968), maintained at subconfluence by regular passaging, were allowed to proliferate in Dulbecco's modified Eagle's medium (DMEM, Life Technologies Ltd, Gaithersberg, MD, USA) buffered with $\mathrm{NaHCO}_{3}(41.9 \mathrm{mmol} / \mathrm{l})$ and gaseous $\mathrm{CO}_{2}$ and containing phenol red $(7 \cdot 22 \mathrm{nmol} / \mathrm{l})$ as a $\mathrm{pH}$ indicator. Foetal bovine serum (FBS, 10\% v/v, Life Technologies Ltd, Auckland, New Zealand), penicillin $\left(1 \times 10^{5} \mathrm{IU} / \mathrm{l}\right.$, Sigma, St Louis, MO, USA) and streptomycin (100 mg/l, Sigma) were routinely added to media. Cell culture flasks and microtitre plates were obtained from Nunc, Roskilde, Denmark. Recombinant human IGF-I was a generous gift from Ciba Geigy, Basel, Switzerland. Horse serum (HS) was obtained from Life Technologies Ltd, New Zealand. DMEM-FBS refers to buffered DMEM media containing FBS as described above, whereas DMEM refers to buffered media without FBS. Before treatment, cells were allowed to attach to the culture vessels overnight at $37^{\circ} \mathrm{C}$ in DMEM-FBS media at a plating density of 15243 cells per $\mathrm{cm}^{2}$ (corresponding to 5000 per microtitre plate well). This cell density, considered to be substantially less than $10 \%$ of confluence, was selected because it was sufficiently low to allow subconfluent growth in positive control wells treated with DMEM-FBS over the course of the experiments. Following attachment and before the addition of treatment media, wells were thoroughly washed using 3 changes of pre-warmed DMEM media.

In experiments carried out following withdrawal of initial (36 h) IGF-I, the following procedure was adopted: cells were allowed to attach to flasks or microtitre plates overnight in DMEM-FBS. Media were washed from the cells using three changes of pre-warmed DMEM media and replaced with DMEM containing $100 \mathrm{ng} / \mathrm{ml}$ IGF-I. Cells were allowed to proliferate for $36 \mathrm{~h}$ at $37^{\circ} \mathrm{C}$, then media were washed from the cells using three changes of pre-warmed DMEM media. Test media were then added to the flasks or microtitre plates. In the case of the experiment designed to test the effect of adding back FBS following $36 \mathrm{~h}$ of IGF-I treatment, DMEM-FBS was added back for $16.25 \mathrm{~h}$ (i.e. for the same time that cells were exposed to DMEM-FBS during overnight attachment), media were then washed from the cells using three changes of pre-warmed DMEM media and DMEM with and without $100 \mathrm{ng} / \mathrm{ml}$ IGF-I was added back for up to $67 \mathrm{~h}$ at $37^{\circ} \mathrm{C}$.

\section{Cell proliferation assay}

Cell proliferation was determined by a modification of the method of Oliver et al. (1989). Briefly, growth media were decanted, cells were washed in Dulbecco A phosphate buffered saline, (Oxoid Ltd, Basingstoke, Hants, UK; PBS) and then fixed for $30 \mathrm{~min}$ in 10\% (v/v) formaldehyde in saline. The fixed cells were stained for $30 \mathrm{~min}$ with $10 \mathrm{~g} / 1$ methylene blue in $0 \cdot 01 \mathrm{M}$ borate buffer $(\mathrm{pH}$ $8 \cdot 5)$. Excess stain was removed by four sequential washes in borate buffer. Methylene blue was eluted from the cells by the addition of $100 \mu \mathrm{l} 1: 1(\mathrm{v} / \mathrm{v})$ ethanol/0.1 M $\mathrm{HCl}$. The plates were gently shaken and optical density was determined at $655 \mathrm{~nm}$ using a microplate photometer (BioRad model 3550 microplate reader, BioRad, Hercules, CA, USA). A plot of absorbance versus cell number was found to be linear in the range of interest (4000 to 30000 cells per $\mathrm{cm}^{2}$, Oliver et al. 1989).

\section{Cell adherence}

When cell suspensions were required for cell counting, cells were washed with PBS then stripped from the plastic surface using 0.25\% trypsin (1:250 grade, Sigma Cell Culture Ltd, St Louis, MO, USA) in PBS. For this, cells were incubated at room temperature until they were observed by microscopic examination to begin to pull away from the surface of the flask; this took approximately $1 \mathrm{~min}$. Trypsin was decanted from the flask and complete detachment of cells from the vessel surface allowed to proceed at $37^{\circ} \mathrm{C}$. This second incubation, also monitored microscopically, took 7-8 min. When a determination of the number of lightly attached cells was required, the second trypsin incubation was omitted, and the lightly attached cells decanted carefully from the surface of the flask. When a determination of the number of free floating cells was required no enzymatic digestion was carried out, media were carefully decanted and wells were washed with PBS with washings added to the decanted cells. Counting was performed using a haemocytometer.

\section{Cell viability}

Cell viability was determined using the trypan blue assay (Sigma Cell Culture Catalogue 1999).

\section{Apoptosis assay}

Sufficient cells for the determination of apoptosis were obtained by seeding $175 \mathrm{~cm}^{2}$ flasks (Nunc) with L6 myoblasts at the same cell density as for microtitre plate wells in the other experiments, i.e. 15243 cells per $\mathrm{cm}^{2}$ in DMEM-FBS. This larger-scale cell production was required in order to generate sufficient cells in the 'IGF-treated combined lightly attached and floating populations' for the apoptosis assay. Following washing with pre-warmed DMEM to remove FBS, proliferation was allowed to proceed for $36 \mathrm{~h}$ in the presence of $100 \mathrm{ng} / \mathrm{ml}$ IGF-I in DMEM. Media were washed from the plates as before and cells were exposed to DMEM with or without 
$100 \mathrm{ng} / \mathrm{ml}$ IGF-I for a further $12 \mathrm{~h}$ at $37^{\circ} \mathrm{C}$. Apoptosis was determined in combined lightly attached and floating populations of cells and in fully adherent populations according to the method of Hermann et al. (1994). This method may underestimate the level of apoptosis, because cells which are in the G2/M phase of the cell cycle and about to divide will not be as adherent as those in other phases and may also lift off with the dying cells following short exposure to trypsin. Briefly, harvested cells $\left(1 \times 10^{6}\right)$ were washed with PBS and lysed using NP-40 detergent in Tris- $\mathrm{HCl}$ buffer, $\mathrm{pH} 7 \cdot 5$. RNA was digested using ribonuclease A (Boehringer Mannheim, Mannheim, Germany) and protein was digested using proteinase $\mathrm{K}$ (Boehringer Mannheim). The cell digest was loaded according to cell number only onto a $1 \%$ agarose gel, containing $200 \mathrm{ng} / \mathrm{ml}$ ethidium bromide and electrophoresed for $1 \mathrm{~h}$ using a constant voltage of $105 \mathrm{~V}$. Bands of DNA were visualised using a Transilluminator (UVP Inc, Upland, CA, USA) and photographed using a Direct Screen Instant Camera (Polaroid, UK).

\section{Data analysis}

Microtitre plate well optical density values for each treatment were averaged and tested for differences using the Student's $t$-test. Methylene blue assay data is expressed as the mean of eight replicates obtained from the same microtitre plate within the one assay, and are representative of the results obtained from several assays.

\section{Results}

The effect of IGF-I and HS was examined in myoblasts to determine whether IGF-I can stimulate myoblast proliferation alone or whether co-factors are required.

\section{Proliferation with IGF-I}

The proliferative response of L6 myoblasts to IGF-I at 10, 100 and $1000 \mathrm{ng} / \mathrm{ml}$ was determined over $48 \mathrm{~h}$ following cell attachment to microtitre plates. Figure 1 shows that L6 myoblasts were dose responsive to IGF-I by $72 \mathrm{~h}$ $(P<0 \cdot 001)$; however this trend was identified from $30 \mathrm{~h}$. By $48 \mathrm{~h}$, cell proliferation in response to IGF-I had stopped and cell numbers were very low compared with the positive control DMEM-FBS treatment, despite the fact that cell cultures remained subconfluent, the addition of further IGF-I did not restore proliferation and harvested conditioned media were equipotent with IGF-I in stimulating proliferation when added to naive cultures. DMEM alone was used as the negative control media in which no cell proliferation was observed.

\section{Proliferation with horse serum}

Horse serum promoted L6 myoblast proliferation in a dose-dependent fashion $(P<0 \cdot 001$, Fig. 2$)$ and this was

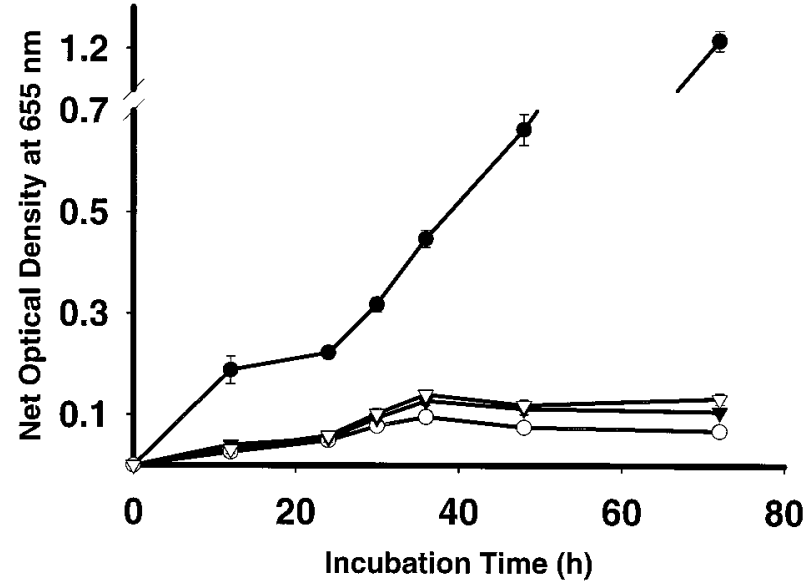

Figure 1 L6 myoblast proliferation IGF-I dose-response curve. Results are means of eight replicate optical density $(655 \mathrm{~nm})$ measurements \pm S.E.M. following staining of cells by methylene blue, and are representative of several assays. Symbols represent positive control media (DMEM-FBS) $(\bullet), 1000 \mathrm{ng} / \mathrm{ml}$ IGF-I $(\nabla)$, $100 \mathrm{ng} / \mathrm{ml}$ IGF-I $(\boldsymbol{\nabla})$ and $10 \mathrm{ng} / \mathrm{ml}$ IGF-I (O). Mean negative control (DMEM alone) values have been subtracted from each value to obtain the 'Net' optical density value.

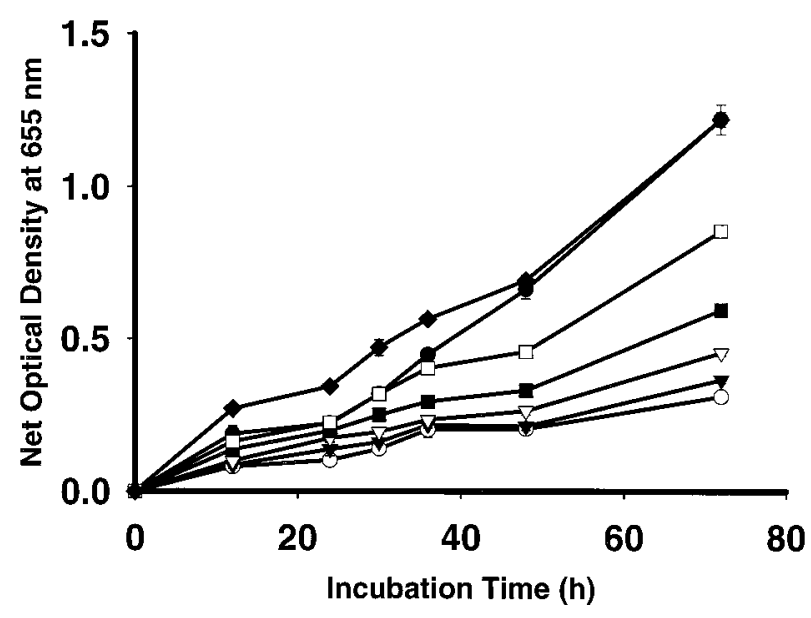

Figure 2 L6 myoblast proliferation horse serum dose-response curve. Results are means of eight replicate optical density $(655 \mathrm{~nm})$ measurements \pm S.E.M. following staining of cells by methylene blue. Symbols represent positive control media $(\mathrm{DMEM}-\mathrm{FBS})(\bullet)$, and DMEM containing $10(\bullet), 5(\square), 2(\mathbf{\square})$, $1(\nabla), 0.5(\boldsymbol{\nabla})$ and $0.3 \%(\mathrm{v} / \mathrm{v})(\bigcirc)$ horse serum. Mean negative control (DMEM alone) values have been subtracted from each value to obtain the 'Net' optical density value.

maintained for $72 \mathrm{~h}$, unlike IGF-I which no longer stimulated proliferation past $30 \mathrm{~h}$. In future trials, $1 \%(\mathrm{v} / \mathrm{v})$ HS was used because of its low effect on cell proliferation.

Proliferation following withdrawal of IGF-I for $36 \mathrm{~h}$

Myoblasts remain essentially quiescent in the presence of either $100 \mathrm{ng} / \mathrm{ml} \mathrm{IGF-I}$ or 1\% HS alone (Fig. 3), but 


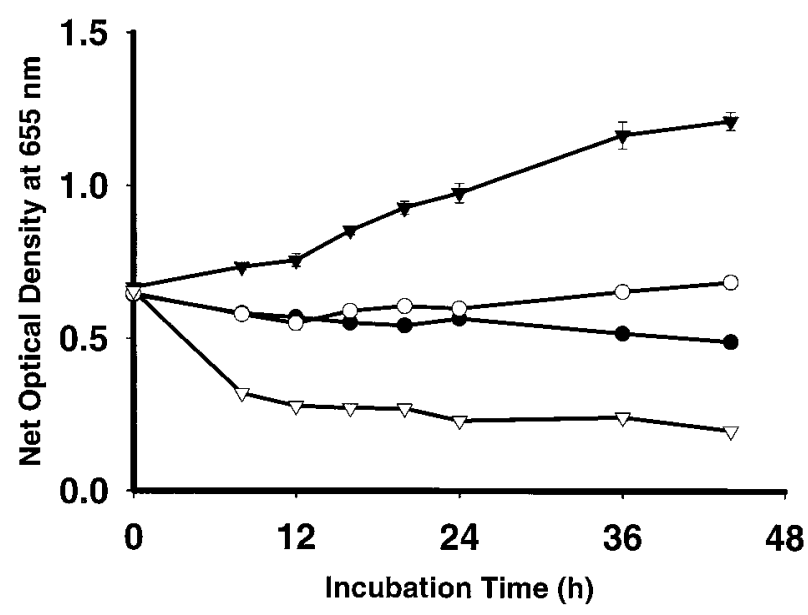

Figure 3 The proliferative effect of IGF-I and horse serum either alone or in combination following withdrawal of initial (36 h) IGF-I from growth media. Results are means of eight replicate optical density $(655 \mathrm{~nm})$ measurements \pm S.E.M. following staining of cells by methylene blue and are representative of several assays. Symbols represent proliferative response to DMEM media containing $100 \mathrm{ng} / \mathrm{ml}$ IGF-I $(\bullet), 1 \%(\mathrm{v} / \mathrm{v})$ horse serum $(\bigcirc)$, $100 \mathrm{ng} / \mathrm{ml}$ IGF-I plus $1 \%(\mathrm{v} / \mathrm{v})$ horse serum $(\boldsymbol{\nabla})$ and DMEM alone $(\nabla)$. L6 myoblasts were plated onto microtitre plates and allowed to attach overnight at $37^{\circ} \mathrm{C}$.

proliferate in the presence of both HS and IGF-I together $(P<0 \cdot 001)$. When DMEM alone was added (without either HS or IGF-I) there was a dramatic reduction $(P<0 \cdot 001)$ in cell numbers after $8 \mathrm{~h}$, after which time cell numbers were stable. When cells were exposed again to DMEM-FBS for a time equivalent to the attachment time, and then had media removed, their capacity to respond to IGF-I was restored, but again only for $36 \mathrm{~h}(P<0 \cdot 001$, Fig. 4).

\section{Cell attachment, viability and apoptosis}

To examine the reduction in cell numbers observed in Fig. 3 with DMEM culture media alone, viability, attachment status and apoptosis of myoblasts were measured.

Flasks of cells were raised specifically to study the change in attachment status and cell death induced by incubation with DMEM alone. After $8 \mathrm{~h}$ incubation with DMEM alone, approximately $46 \%$ of the cells were no longer firmly attached to the surface of the culture vessel (Table 1). Of the total cells present following this treatment, 13\% had completely detached from the surface and were floating free in the media, 33\% of the total cells were attached only very weakly and, as discussed in the Materials and Methods section, required minimal exposure to trypsin digestion in order to detach them from the surface. Of the $13 \%$ of cells that were floating free, $60 \%$ were dead as determined by the trypan blue assay.

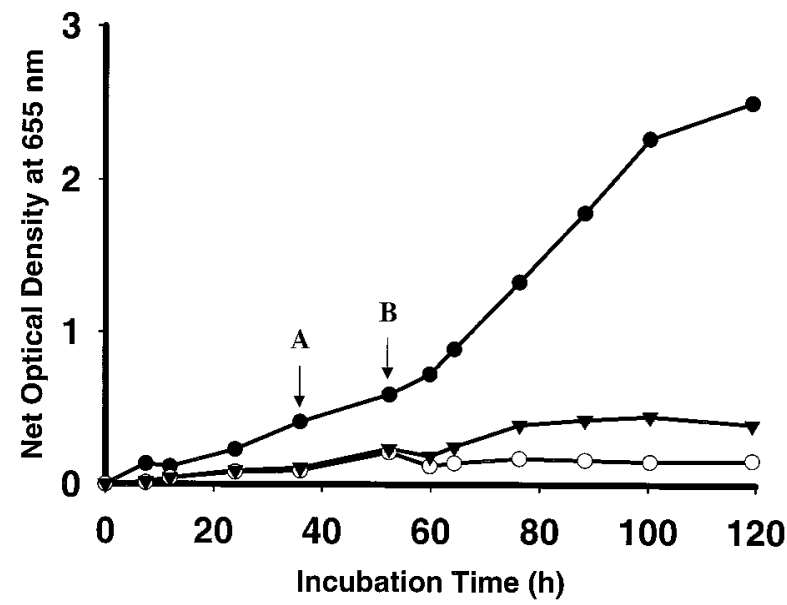

Figure 4 The effect of a second exposure to fetal bovine serum on the capacity of L6 myoblasts to respond to IGF-I. Results are expressed as the means of eight replicate optical density $(655 \mathrm{~nm})$ measurements \pm S.E.M. following staining of cells by methylene blue, and are representative of several assays. Following overnight attachment in positive control media (DMEM-FBS), L6 myoblasts were exposed for $36 \mathrm{~h}$ to DMEM-FBS $(\bullet)$ or to DMEM containing $100 \mathrm{ng} / \mathrm{ml}$ IGF-I ( $\boldsymbol{\nabla}$ and $\bigcirc$ ). Media were then washed from the wells (A), and DMEM-FBS added back to each treatment group for $16 \cdot 25 \mathrm{~h}$. Media were again washed from the wells (B) and DMEM-FBS $(\mathbf{O})$ or DMEM with $(\boldsymbol{\nabla})$ or without $(\bigcirc) 100 \mathrm{ng} / \mathrm{ml}$ IGF-I was added back for a further $67 \mathrm{~h}$. Mean negative control (DMEM alone) values have been subtracted from each value to obtain the 'Net' optical density value.

Table 1 shows the cell numbers present following each treatment regime and is in agreement with the results presented in Fig. 3.

\section{Apoptosis}

Apoptosis was determined (see Fig. 5) in cell populations following $12 \mathrm{~h}$ treatment with DMEM alone or with $100 \mathrm{ng} / \mathrm{ml}$ IGF-I after withdrawal of the initial $(36 \mathrm{~h})$ IGF-I treatment. DNA laddering, as a measure of apoptosis, was much greater in combined floating and lightly attached populations of cells in the absence of IGF-I than in the other treatment groups.

\section{Discussion}

L6 myoblast proliferation in these studies was doseresponsive to IGF-I up to $48 \mathrm{~h}$, confirming earlier work (Ballard et al. 1986, Ewton et al. 1987, Moore et al. 1993). Although myoblasts proliferated in response to IGF-I, they did so for only 30 to $36 \mathrm{~h}$, regardless of concentration. This confirms the earlier findings in L6A1 myoblasts by McWade et al. (1995) who found that IGF-I stimulates myoblast proliferation for only $36 \mathrm{~h}$.

L6 myoblast proliferation was dose-responsive to horse serum and this is supported by the findings of Allen et al. 
Table 1 L6 myoblast cell numbers following different treatment regimes

\begin{tabular}{|c|c|c|c|c|}
\hline \multirow[b]{2}{*}{ Population } & 100 ng/ml IGF-I & $1 \%(v / v) H S$ & $\begin{array}{l}100 \mathrm{ng} / \mathrm{ml} \text { IGF-I } \\
+1 \%(\mathrm{v} / \mathrm{v}) \mathrm{HS}\end{array}$ & DMEM alone \\
\hline & & & & \\
\hline Firmly attached & 152133 (1555) & 157080 & $196000 \quad(0)$ & 70933 (1867) \\
\hline Lightly attached & 22333 (1680) & $23000(2000)$ & $5667(333)$ & 43040 (1144) \\
\hline Floating & 7667 (3333) & $19680(4000)$ & $1000 \quad(0)$ & 17667 (10667) \\
\hline Total & $182133(5013)$ & $199760(6000)$ & 202667 (333) & 131640 (13678) \\
\hline
\end{tabular}

Figures in parentheses represent the number of dead cells as determined using the trypan blue method. Cells were allowed to attach to the culture vessel overnight in the presence of DMEM-FBS. Media were washed from the cells, replaced with DMEM containing $100 \mathrm{ng} / \mathrm{ml}$ IGF-I, and incubation was allowed to proceed for $36 \mathrm{~h}$ after which the starting cell number was 177333 per well. Media were washed from the cells and DMEM containing either $100 \mathrm{ng} / \mathrm{ml} \mathrm{IGF-I,} \mathrm{1 \% (v/v)} \mathrm{HS,} \mathrm{both} \mathrm{IGF-I} \mathrm{and} \mathrm{HS,} \mathrm{or} \mathrm{neither} \mathrm{was}$ added and incubation allowed to proceed for $12 \mathrm{~h}$. Cells were counted using a haemocytometer and 'Firmly attached', 'Lightly attached' and 'Floating' refer, respectively, to populations of cells that required long (8-9 min), short (1 $\mathrm{min}$ ) or no exposure to trypsin to detach from the surface of the vessel.

(1982) for HS with chick embryo myogenic cells, White et al. (1988) for adult porcine serum with L6M1 myoblasts and Kotts et al. (1987) for swine serum with a clone of L6 myoblasts. We found that whereas IGF-I stimulated L6 myoblasts for $36 \mathrm{~h}$, the cells remained responsive to HS for at least $48 \mathrm{~h}$.

When both IGF-I and HS were added to cells that had stopped proliferating after an initial $36 \mathrm{~h}$ of IGF-I treat-

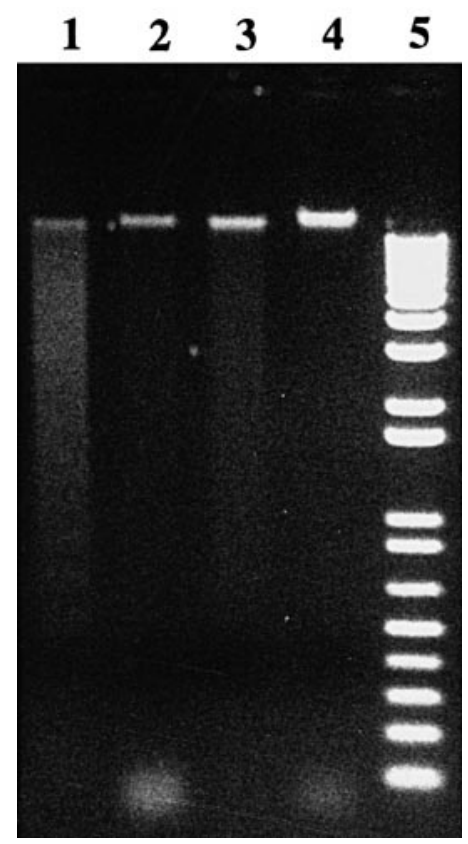

Figure 5 1\% Agarose gel showing DNA fragmentation as a determination of apoptosis. Lanes show DNA from cells treated as follows: lane 1, DMEM (combined lightly attached and floating populations); lane 2, DMEM (fully attached cells); lane 3, IGF-I (combined lightly attached and floating populations); lane 4, IGF-I (fully attached cells); lane 5, marker (1 kb plus ladder from Life Technologies Inc, Gaithersberg, MD, USA). The gel contained ethidium bromide to allow visualisation of DNA bands. ment, proliferation was restored; however HS had little or no mitogenic activity in the absence of IGF-I in these cells. This is consistent with the findings of McWade et al. (1995), in which they describe an activity in HS as a mitogenic competence factor (MCF) which was able to restore IGF-I-stimulated proliferation of L6A1 myoblasts, but which had no mitogenic activity on its own. When neither IGF-I nor HS were added back to the L6 cells a dramatic decline in cell numbers was identified using the methylene blue assay as well as by direct cell counting and no mention was made of this finding in McWade and colleagues' 1995 abstract. Stewart and Rotwein (1996), however, using direct counting of stably transfected IGF-II antisense C2 cells, reported a similar effect when they changed from 10\% FBS-containing media to differentiation media (containing 2\% HS). They were able to arrest the rapid decline in the number of adherent, viable myoblasts using either IGF-I or cycloheximide. Clearly IGF-I in some way protects the cells from a decline in number. In our studies we were also able to arrest the decline using HS.

Our results clearly show that myoblasts require some factor or factors that are to be found in horse serum in order to proliferate in response to IGF-I. It appears from first sight that IGF-I alone is able to stimulate cell proliferation for the first $36 \mathrm{~h}$. This would indicate that (i) actively growing cells do not require a competence factor to proliferate in response to IGF-I, (ii) that sufficient of this factor is taken up from FBS at the time of attachment to last for $36 \mathrm{~h}$ or (iii) that FBS at attachment moves cells into the cell cycle where they can respond to the proliferative signal of IGF-I. Following $36 \mathrm{~h}$ of serum starvation, the addition of HS may serve to move the cells back into the cell cycle where they can respond to IGF-I. This effect of serum is likely to be multi-factorial. MCF has been described as being distinct from transforming growth factor- $\beta$, plateletderived growth factor-BB, transferrin, known IGF binding proteins, fibroblast growth factor, fetuin or a general effect of proteins (McWade et al. 1995, 1997). 
Agarose gel electrophoresis established that the combined population of floating and lightly attached cells underwent significant apoptosis compared with fully attached cells as determined by the characteristic laddering profile. When taken together with the fact that IGF-I protects cells from declining in number past $36 \mathrm{~h}$, this suggests that IGF-I protects the cells from apoptosis. There appears to be two populations of cells, as initially there is a significant loss of cells up to 8 to $12 \mathrm{~h}$ after removal of IGF-I from the media; after that time the cells are quiescent but do not die, and proliferation can be restored if the cells are stimulated with FBS. There may be different cell types, or cells that are at different stages of the cell cycle within the L6 cultures. Apoptosis under conditions of substrate detachment is consistent with the findings of Stewart and Rotwein (1996) who showed that apoptosis in C2 myoblasts could be arrested with IGF-I, des[1-3]IGF-I, IGF-II or insulin, with a dose potency consistent with the activation of the type 1 IGF receptor. In addition to this work, other investigators have reported IGF-I as protecting other cultured cell lines from apoptosis (Rodriguez-Tarduchy et al. 1992, Muta \& Krantz 1993, Sell et al. 1995).

While we did detect apoptosis in combined lightly attached and floating populations following IGF-I treatment, the total number of cells in this treatment group was very low.

This study has shown that IGF-I does require a co-factor to stimulate proliferation of myoblasts under specific circumstances. Whether a co-factor is always required for maximum stimulation of proliferation is not known; however a reduced external co-factor requirement in early proliferation is at least indicated from our results. IGF-I-mediated myoblast survival is not necessarily associated with proliferation. This is in agreement with Harrington et al. (1994) who have shown a separation of function for IGF-I in fibroblasts. Our results clearly show that IGF-I-stimulated proliferation and cell survival can be separated and that proliferation requires another factor or factors. In conclusion we have described two distinct actions for IGF-I. IGF-I stimulates proliferation of subconfluent L6 myoblasts in the presence of a mitogenic competence factor and it is also able to inhibit apoptosis on its own.

\section{Acknowledgements}

We wish to acknowledge the support of the New Zealand Foundation for Research, Science and Technology. We are also grateful to Dr Neil Cox for performing statistical analyses.

\section{References}

Allen RE, Robinson G, Parsons MJ, Merkel RA \& Magee WT 1982 Age-related changes in the effects of serum from lean and obese pigs on myogenic cell proliferation in vitro. Journal of Animal Science 54 763-768.

Ballard FJ, Read LC, Francis GL, Bagley CJ \& Wallace JC 1986 Binding properties and biological potencies of insulin-like growth factors in L6 myoblasts. Biochemical Journal 233 223-230.

D’Mello SR, Galli C, Ciotti T \& Calissano P 1993 Induction of apoptosis in cerebellar granule neurons by low potassium: inhibition of death by insulin-like growth factor-I and cAMP. Proceedings of the National Academy of Sciences of the USA 90 10989-10993.

Ewton DZ \& Florini JR 1981 Effect of somatomedins and insulin on myoblast differentiation in vitro. Developmental Biology 86 31-39.

Ewton DZ, Falen SL \& Florini JR 1987 The type II insulin-like growth factor (IGF) receptor has low affinity for IGF-I analogs: pleiotypic actions of IGFs on myoblasts are apparently mediated by the type I receptor. Endocrinology 120 115-123.

Harrington EA, Bennet MR, Fanidi A \& Evan GI 1994 c-Mycinduced apoptosis in fibroblasts is inhibited by specific cytokines. EMBO Journal 13 3286-3295.

Hermann M, Lorenz H-M, Voll R, Grünke M, Woith W \& Kalden JR 1994 A rapid and simple method for the isolation of apoptotic DNA fragments. Nucleic Acids Research 22 5506-5507.

Kotts CE, White ME, Allen CE, Martin F \& Dayton WR 1987 A statistically standardized muscle cell culture bioassay measuring the effect of swine serum on muscle cell proliferation. Journal of Animal Science 64 615-622.

McWade FJ, Ewton DZ \& Florini JR 1995 Mitogenic competence factor, a serum component that is necessary for IGF-I to stimulate myoblast proliferation and suppresses their ability to stimulate differentiation. Proceedings of the 77th Annual Meeting of the American Endocrine Society, Washington DC. Abstract P3-206.

McWade FJ, Ewton DZ, Coolican SA \& Florini JR 1997 Essential role of the mitogenic competence factor (MCF) in mitogenic actions of IGF-I. Proceedings of the 79th Annual Meeting of the American Endocrine Society, Minneapolis, Minnesota. Abstract P1-187.

Moore LG, Jones D, Lymburn MA, Hodgkinson SC, Davis SR, Suttie JM, Sadighi M \& Carne A 1993 Isolation and sequencing of deer and sheep insulin-like growth factors-I and -II. General and Comparative Endocrinology 92 302-310.

Muta K \& Krantz SB 1993 Apoptosis of human erythroid colonyforming cells is decreased by stem cell factor and insulin-like growth factor-I as well as erythropoietin. Journal of Cellular Physiology 156 264-271.

Oliver MH, Harrison NK, Bishop JE, Cole PJ \& Laurent GJ 1989 A rapid and convenient assay for counting cells cultured in microtitre plates: application for assessment of growth factors. Journal of Cell Science 92 513-518.

Rodriguez-Tarduchy G, Collins MKL, Garcia I \& Lopez-Rivas A 1992 Insulin-like growth factor-I inhibits apoptosis in IL-3dependent hemopoietic cells. Journal of Immunology 149 535-540.

Sell C, Baserga R \& Rubin R 1995 Insulin-like growth factor-I (IGF-I) and the IGF-I receptor prevent etoposide-induced apoptosis. Cancer Research 55 303-306.

Stewart CEH \& Rotwein P 1996 Insulin-like growth factor-II is an autocrine survival factor for differentiating myoblasts. Journal of Biological Chemistry 271 11330-11338.

White ME, Allen CE \& Dayton WR 1988 Effect of sera from fed and fasted pigs on proliferation and protein turnover in cultured myogenic cells. Journal of Animal Science 66 34-40.

Yaffe D 1968 Retention of differentiation potentialities during prolonged cultivation of myogenic cells. Proceedings of the National Academy of Sciences of the USA 61 477-483.

Received 20 October 1998

Revised manuscript received 7 April 1999

Accepted 27 May 1999 